\title{
Validation of a cardiac risk factor index for noncardiac surgery in a community osteopathic hospital
}

\author{
KAREN J. NICHOLS, D.O. \\ Mesa, Arizona \\ KAREN E. DANIELS, D.O. \\ Tulsa, Oklahoma
}

\begin{abstract}
About 10 years ago, Goldman and associates retrospectively developed a multifactorial index of cardiac risk in noncardiac surgical patients. Their work was widely used and cited, but there has been little prospective validation. A study of this risk factor index in 609 patients undergoing noncardiac surgery at a community osteopathic hospital revealed accurate prediction of cardiac risks. Possible reasons for some variations seen in frequency of occurrence of risk factors and risk prediction are discussed.
\end{abstract}

Evaluation of patients for cardiac risk factors in noncardiac surgery remains a crucial part of the perioperative management of surgical patients. With the rising population of elderly persons and more advanced operative techniques, surgeons and internists who examine these patients preoperatively are more frequently faced with the problem of cardiac complications.

The average American adult has approximately a 0.2 percent risk of myocardial infarction or death. ${ }^{1,2}$ Several studies ${ }^{1,3-5}$ have shown that recent preoperative myocardial infarction carries a greatly increased risk; that is, 30 percent of patients who undergo surgery within 3 months after infarction and 15 percent of patients who are operated on between 3 and 6 months postinfarction will suffer recurrent myocardial infarction or cardiac death. After 6 months postinfarction, the risk drops to about 5 percent and remains fairly constant. Additionally, studies by Skinner ${ }^{6}$ and Goldman ${ }^{7,8}$ have shown that preoperative congestive heart failure increases surgical risk. These factors, along with age, site of surgery, whether the procedure was an emergency or elective one, and general med- ical health, all play a role in determining the patient's cardiac risk.

In an attempt to identify the patient at cardiac risk, Goldman and associates ${ }^{4}$ studied a series of 1,001 patients older than 40 years of age who underwent general anesthesia. By using multivariate analysis, nine risk factors were developed; these factors were weighted by assigning points to each (Table 1). The patient's score was then determined by the total point sum, and he/she was grouped into one of four classes, as follows: class I, 0-5 points; class II, $6-12$ points; class III, $13-25$ points; and class IV, $>26$ points.

Goldman and associates' index was derived retrospectively; therefore, it needs prospective testing in community hospitals to determine its usefulness. The purpose of the present prospective study was to validate Goldman and associates' multifactorial index score in a community osteopathic hospital.

\section{Methods}

Between January and September 1984, 8,569 surgical procedures were performed at our institution. From these cases, 1,000 patients met the study group criteria-persons older than 40 years who were to receive general anesthesia for noncardiac surgical procedures. Of these, 609 patients were selected randomly for study. The patient population was sampled from general, orthopedic, gynecologic, and urologic surgical services.

For each study subject, the risk factors of S3 gallop or jugular venous distention, myocardial infarction during the previous 6 months, valvular aortic stenosis, and age were evaluated preoperatively by history taking and physical examination by housestaff or attending physicians, including internists and surgeons. This information was then noted on a patient abstract form. The remaining factors (electrocardiographic abnormalities, general health status, laboratory values, and operative site and type of procedure 
[emergency versus elective]) were assessed by the authors by reviewing the patient's chart.

Each patient was given a cardiac risk factor score, as computed from Goldman and associates' criteria. The patient's outcome for cardiac complications or cardiac death was then assessed from the chart by the authors.

\section{Results}

In ths study, 3 cardiac deaths occurred. Of the 24 diagnosed life-threatening complications, 21 were ventricular tachycardia; there was 1 myocardial infarction and 2 instances of congestive heart failure postoperatively. Table 2 correlates the number and percentage of patients in each class with each degree of complication. Of the 450 class I patients, only 3 ( 0.7 percent) had life-threatening complications, and there were no deaths. The 122 class II patients suffered 9 life-threatening complications ( 7.4 percent), and there were 2 cardiac deaths (1.6 percent). There were 11 (31.4 percent) complications and 1 death ( 2.9 percent) among the

TABLE 1. COMPUTATION OF MULTIFACTORIAL INDEX SCORE TO ESTIMATE CARDIAC RISK IN NONCARDIAC SURGERY (ADAPTED FROM GOLDMAN AND ASSOCIATES ${ }^{4}$ ).

\begin{tabular}{|c|c|}
\hline Risk factor & Point \\
\hline S3 gallop or jugular venous diste & 11 \\
\hline Transmural or subendocardial myocardial & 10 \\
\hline \multicolumn{2}{|l|}{ Premature ventricular beats (more than 5 per } \\
\hline \multicolumn{2}{|l|}{$\begin{array}{l}\text { Rhythm other than sinus rhythm or presence of } \\
\text { premature atrial contractions }\end{array}$} \\
\hline & 7 \\
\hline Ag & 5 \\
\hline Em & 4 \\
\hline of surgery & 3 \\
\hline Evi & 3 \\
\hline Poo & 3 \\
\hline \multicolumn{2}{|l|}{$\begin{array}{l}\text { *Findings of a cardiologist's examination, noninvasive testing, or } \\
\text { cardiac catheterization. } \\
\text { †As evidenced by electrolyte abnormalities (potassium level, }<3.0 \\
\text { mEq. } / \mathrm{L} \text {; bicarbonate value, }<20 \mathrm{mEq} . / \mathrm{L} \text {.), renal insufficiency (blood } \\
\text { urea nitrogen value, }>50 \mathrm{mg} . / \mathrm{dl} \text {., serum creatinine level, }>3.0 \mathrm{mg} . / \\
\text { dl.), abnormal blood gases }\left(\mathrm{PO}_{2},<60 \mathrm{~mm} . \mathrm{Hg} ; \mathrm{PCO}_{2},>50 \mathrm{~mm} \text {. } \mathrm{Hg} \text { ), }\right. \\
\text { abnormal liver status (elevated aspartate transaminase level or signs } \\
\text { of chronic liver disease on physical examination), or any condition } \\
\text { that has caused the patient to be bedridden chronically. }\end{array}$} \\
\hline
\end{tabular}

35 class III patients. There were only 2 class IV patients, with 1 suffering a life-threatening complication.

\section{Discussion}

Patients were selected for this study using the same criteria as those used by Goldman and associates ${ }^{4}$ in computing their risk factor index so that we could reproduce their study as closely as possible.

In our study, 94 percent of all patients were grouped into classes I and II, while only 6 percent were categorized into classes III and IV (Table 2). In comparison, Goldman and associates' study had 85 percent of all patients in classes I and II and 15 percent in classes III and IV (Table 3). Several factors may have contributed to the different distribution of patients in our study. Goldman and associates' study was conducted at Massachusetts General Hospital, a tertiary referral center. Our study was conducted in a 500-bed osteopathic community hospital, which has some referred patients from outlying rural hospitals but mainly serves the community in which it is located. Therefore, our patient population may have been less ill than that studied by Goldman and associates. It may also be possible that stricter criteria are exercised in selection of patients for surgery at our hospital, and, therefore, that the more severely ill patients were never entered into our study because they were not considered surgical candidates. Another possibility is that in the 9 years ensuing between Goldman and associates' and our studies, advancements in medical management techniques and more effective medications may have allowed upgrading of some patients into less severe categories. As Gold$\operatorname{man}^{9}$ pointed out, 25 of the 50 points in the risk factor index are remediable. It would be expected that progress in medical technology would allow these factors to be more readily identified and remediated.

We elected to conduct this study as a true reflection of actual presurgical evaluation in our institution. Housestaff (interns and residents) were instructed at the beginning of this study in the

TABLE 2. CARDIAC COMPLICATIONS AND DEATHS ACCORDING TO CLASS IN STUDY POPULATION OF 609 PATIENTS.

\begin{tabular}{|lcrc|}
\hline & $\begin{array}{c}\text { No or minor } \\
\text { complication } \\
(\mathrm{n}=582)\end{array}$ & $\begin{array}{c}\text { Life-threatening } \\
\text { complication } \\
(\mathrm{n}=24)\end{array}$ & $\begin{array}{c}\text { Cardiac } \\
\text { deaths } \\
(\mathrm{n}=3)\end{array}$ \\
\hline I $\quad(\mathrm{n}=450)$ & $447(99.3 \%)$ & $3(0.7 \%)$ & $0(0.0 \%)$ \\
II $(\mathrm{n}=122)$ & $111(91.0 \%)$ & $9(7.4 \%)$ & $2(1.6 \%)$ \\
III $(\mathrm{n}=35)$ & $23(65.7 \%)$ & $11(31.4 \%)$ & $1(2.9 \%)$ \\
IV $(\mathrm{n}=2)$ & $1(50.0 \%)$ & $1(50.0 \%)$ & 0 \\
\hline
\end{tabular}

*Percentage of each class with listed outcome. Ninety-four percent of the total study group were categorized as class I and class II patients, and 6 percent were categorized as class III and class IV patients. 
TABLE 3. CARDIAC COMPLICATIONS AND DEATHS ACCORDING TO CLASS IN STUDY POPULATION OF 1,001 PATIENTS (ADAPTED FROM GOLDMAN AND ASSOCIATES ${ }^{4}$ ).

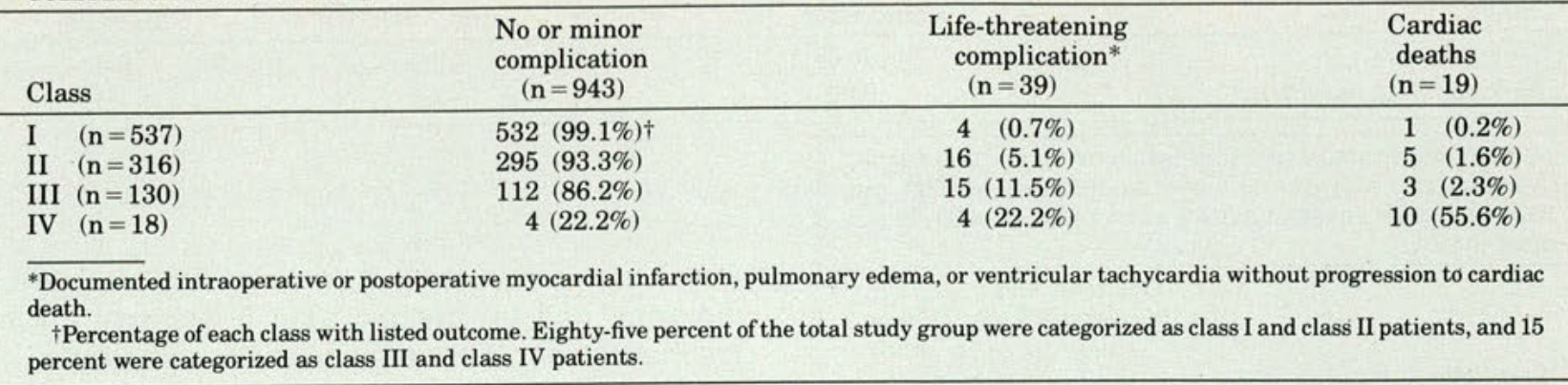

evaluation of historic and physical factors, and a recording form was provided in all patient charts. This form was completed as part of the daily admission or preoperative evaluation process. In the evaluation of these forms by the authors, it was apparent that S3 gallop, jugular venous distention, and chronic liver disease were seldom noted as being present. The number of patients with these risk factors may have been accurately identified, but the low number may also reflect the difficulty in assessing these factors. If these factors were underevaluated, the high number of points given for an S3 gallop or jugular venous distention may have resulted in more patients being categorized into class I or II, when they should have been placed in class III or IV. However, we elected not to audit the forms, so that they would reflect the actual clinical situation in which this risk factor index would be used.

The historic risk factors (myocardial infarction in the previous 6 months, aortic stenosis diagnosed by a cardiologist, and patient's age) were relatively easy to document when the patient cooperated. The rest of the risk factors were obtained from the patient's charts (electrocardiographic and laboratory data). The ability to identify more than 5 premature ventricular contractions per minute at any time prior to surgery was directly proportional to the presence of preoperative cardiac monitoring or previous admissions that involved cardiac monitoring or electrocardiography.

Table 4 presents the comparison of risk factor incidence between all patients in this study and all those studied by Goldman and associates. The most common risk factors in both studies were intraperitoneal, intrathoracic, or aortic sites of operation, age older than 70 years, and poor general medical condition. The occurrence of each risk factor were parallel, except that Goldman and associates' study found that emergency operation was performed in 19.7 percent of patients, while emer-
TABLE 4. COMPARISON OF RISK FACTOR INCIDENCES BETWEEN PRESENT STUDY AND GOLDMAN AND ASSOCIATES' STUDY.

\begin{tabular}{|c|c|c|}
\hline Risk factor & $\begin{array}{l}\text { Goldman and } \\
\text { associates'4 } \\
\text { study } \\
(\mathrm{n}=1,001)\end{array}$ & $\begin{array}{l}\text { Current } \\
\text { study } \\
(\mathrm{n}=609)\end{array}$ \\
\hline $\begin{array}{l}\text { S3 gallop or jugular venous } \\
\text { distention on preoperative } \\
\text { physical examination }\end{array}$ & $35 \quad(3.5 \%)$ & $13(2.1 \%)$ \\
\hline $\begin{array}{l}\text { Transmural or subendocar- } \\
\text { dial myocardial infarction } \\
\text { in the previous } 6 \text { months }\end{array}$ & $22(2.2 \%)$ & $5(0.8 \%)$ \\
\hline $\begin{array}{l}\text { Premature ventricular beats } \\
\text { (more than } 5 \text { per minute } \\
\text { documented at any time) }\end{array}$ & $44 \quad(4.4 \%)$ & $41 \quad(6.7 \%)$ \\
\hline $\begin{array}{l}\text { Rhythm other than sinus rhythm } \\
\text { or presence of premature atrial } \\
\text { contractions on last pre- } \\
\text { operative electrocardiogram }\end{array}$ & $112(11.2 \%)$ & $19(3.1 \%)$ \\
\hline High-risk site of surgery & $437(43.7 \%)$ & $213(35.0 \%)$ \\
\hline Age over 70 years & $324(32.4 \%)$ & $131(21.5 \%)$ \\
\hline Aortic stenosis & $23(2.3 \%)$ & $11(1.8 \%)$ \\
\hline Emergency operation & $197(19.7 \%)$ & $23(3.8 \%)$ \\
\hline Poor general medical condition & $362(36.2 \%)$ & $116(19.1 \%)$ \\
\hline
\end{tabular}

gency surgery was performed in only 3.8 percent of our patients.

The evaluation of patient outcomes was not difficult if there were no, minor, or life-threatening complications, as defined by Goldman. Sometimes it was difficult to determine whether the cause of death was cardiac because of the multifactorial underlying problems in these patients. Only 1 of the 3 patients who died from apparent cardiac events was autopsied to verify the cause of death.

In our institution, 95.6 percent of the total study population had no or minor complications, and 3.9 percent had life-threatening complications or died. In Goldman and associates' study, the outcomes were nearly identical, at 94.2 percent and 3.9 percent, respectively. There were 0.5 percent cardiac deaths in our study and 1.9 percent cardiac deaths in Goldman and associates' study (Table 5).

A comparison of all risk factors found in those patients with life-threatening complications or cardiac deaths in both studies is presented in Table 6 . In order of occurrence, the most common risk factors in the two studies were: (1) intraperitoneal, 


\begin{tabular}{|lccc|}
\hline TABLE 5. COMPARISON OF COMPLICATION INCIDENCES BETWEEN PRESENT STUDY AND GOLDMAN AND ASSOCIATES' STUDY. & $\begin{array}{c}\text { Life-threatening } \\
\text { complication }(\%)\end{array}$ & $\begin{array}{c}\text { Cardiac } \\
\text { death (\%) }\end{array}$ \\
\hline Study & complication $(\%)$ & 3.9 & 0.5 \\
\hline Current & 95.6 & 3.9 & 1.9 \\
Goldman and associates ${ }^{4}$ & 94.2 & . & \\
\hline
\end{tabular}

TABLE 6. COMPARISON OF INCIDENCES OF LIFE-THREATENING COMPLICATIONS/CARDIAC DEATHS ACCORDING TO RISK FACTORS BETWEEN PRESENT STUDY AND GOLDMAN AND ASSOCIATES' STUDY.

\begin{tabular}{|lcr|}
\hline & $\begin{array}{c}\text { Goldman and } \\
\text { associates' } \\
\text { study } \\
(\mathrm{n}=58)\end{array}$ & $\begin{array}{c}\text { Current } \\
\text { study } \\
(\mathrm{n}=27)\end{array}$ \\
\hline Risk factor & & \\
\hline $\begin{array}{l}\text { S3 gallop or jugular venous } \\
\text { distention on preoperative } \\
\text { physical examination }\end{array}$ & $12(20.7 \%)$ & $2 \quad(7.4 \%)$ \\
$\begin{array}{l}\text { Transmural or subendocar- } \\
\text { dial myocardial infarction }\end{array}$ & & \\
in the previous 6 months & $8(13.8 \%)$ & $1 \quad(3.7 \%)$ \\
$\begin{array}{l}\text { Premature ventricular beats } \\
\text { (more than 5 per minute }\end{array}$ & & \\
$\quad$ documented at any time) & $13(22.4 \%)$ & $10(37.0 \%)$ \\
Rhythm other than sinus rhythm & & \\
$\quad$ or presence of premature atrial & & \\
$\quad$ contractions on last pre- & & \\
$\quad$ operative electrocardiogram & $21(36.2 \%)$ & $6(22.2 \%)$ \\
High-risk site of surgery & $43(74.1 \%)$ & $18(66.7 \%)$ \\
$\begin{array}{l}\text { Age over 70 years } \\
\text { Aortic stenosis }\end{array}$ & $35(60.3 \%)$ & $11(40.7 \%)$ \\
Emergency operation & $4(6.9 \%)$ & $3(11.1 \%)$ \\
Poor general medical condition & $26(44.8 \%)$ & $6(22.2 \%)$ \\
\hline
\end{tabular}

TABLE 7. COMPARISON OF CLASSES I/II PATIENTS WHO HAD LIFE-THREATENING COMPLICATIONS OR CARDIAC DEATH WITH CLASSES I/II PATIENTS WHO HAD NO OR MINOR COMPLICATIONS.

\begin{tabular}{|c|c|c|}
\hline Risk factor & $\begin{array}{l}\text { Life-threatening } \\
\text { complication/ } \\
\text { cardiac death } \\
(\mathrm{n}=14)\end{array}$ & $\begin{array}{c}\text { No or } \\
\text { minor } \\
\text { complication } \\
(\mathrm{n}=558)\end{array}$ \\
\hline $\begin{array}{l}\text { S3 gallop or jugular venous } \\
\text { distention on preoperative } \\
\text { physical examination }\end{array}$ & & \\
\hline $\begin{array}{l}\text { Transmural or subendocar- } \\
\text { dial myocardial infarction } \\
\text { in the previous } 6 \text { months }\end{array}$ & $\begin{array}{ll}0 & (0.0 \%)\end{array}$ & $3 \quad(0.5 \%)$ \\
\hline $\begin{array}{l}\text { In the previous } 6 \text { months } \\
\text { Premature ventricular beats } \\
\text { (more than } 5 \text { per minute } \\
\text { documented at any time) }\end{array}$ & $2(14.3 \%)$ & $2(0.4 \%)$ \\
\hline $\begin{array}{l}\text { Rhythm other than sinus rhythr } \\
\text { or presence of premature atria } \\
\text { contractions on last pre- } \\
\text { operative electrocardiogram }\end{array}$ & $1(7.1 \%)$ & $6(1.1 \%)$ \\
\hline High-risk site of surgery & $9(64.3 \%)$ & $181(32.4 \%)$ \\
\hline Age over 70 years & $4(28.6 \%)$ & $105(18.8 \%)$ \\
\hline Aortic stenosis & $0 \quad(0.0 \%)$ & $5 \quad(0.9 \%)$ \\
\hline Emergency operation & $3(21.4 \%)$ & $15(2.7 \%)$ \\
\hline Poor general medical condition & $10(71.4 \%)$ & $90(16.1 \%)$ \\
\hline
\end{tabular}

intrathoracic, or aortic site of operation; (2) poor general medical condition; (3) age greater than 70 years; and (4) emergency operation (Goldman and associates) or more than 5 premature ventricular contractions per minute (current study); (5) rhythm other than sinus rhythm or premature atrial contraction on last preoperative electrocardiogram; and (6) greater than 5 premature contractions per minute (Goldman and associates) or emergency operation (current study).

There were mostly minor differences in the occurrence of risk factors in the two groups, with the exception of a higher incidence of gallop or jugular venous distention in Goldman and associates' study (possibly for reasons previously discussed), and the infarction rate, which was 13.8 percent versus 3.7 percent for ours. Again, a higher incidence of emergency operations was seen in Goldman and associates' study, and a larger percentage of their patients were over 70 years of age.

The question arises as to the proper distribution of the outcomes in relation to the risk classes. The premise of the classification system is that class I and class II patients should have no or only minor complications and that class III and class IV patients would be most likely to have life-threatening complications or cardiac deaths. By applying that premise, 94 percent $(571 / 609)$ of patients in our study and 86 percent $(859 / 1,001)$ of patients in Goldman and associates' study were classified correctly.

A reevaluation of the charts of class I and class II patients with a life-threatening complication or cardiac death was undertaken to determine the causes of these serious outcomes in these lower risk patients. These patients were generally extremely ill with problems that were not reflected in the risk factor categories. Of these 14 patients, 8 (57 percent) had severe underlying cardiac disease but only two risk factors-more than 5 premature ventricular beats per minute and arrhythmias. The other 6 patients ( 43 percent) had severe underlying illness not reflected in the risk factors, other than in the low-point risk factor of poor general medical condition (gangrene, miliary tuberculosis, peritonitis with abscess, fulminant aspiration pneumonia, or multiple fractures from a plane crash). Table 7 compares the risk factor incidence of class I and class II patients who had no or minor complications with those who had life-threatening complications or death. In both sets of patients, the site of the surgical procedure, patient age older than 70 years, and poor general medical condition were the most common risk factors. However, there were much higher percentages of patients with poor gen- 
TABLE 8. COMPARISON OF CLASSES III/IV PATIENTS WHO HAD NO OR MINOR COMPLICATIONS WITH CLASSES III/IV PATIENTS WHO HAD LIFE-THREATENING COMPLICATIONS OR CARDIAC DEATH.

\begin{tabular}{|c|c|c|}
\hline Risk factor & $\begin{array}{l}\text { No or minor } \\
\text { complication } \\
(\mathrm{n}=24)\end{array}$ & $\begin{array}{l}\text { Life-threatening } \\
\text { complication/ } \\
\text { cardiac } \\
\text { death } \\
(\mathrm{n}=13)\end{array}$ \\
\hline $\begin{array}{l}\text { S3 gallop or jugular venous } \\
\text { distention on preoperative } \\
\text { physical examination }\end{array}$ & $8(33.3 \%)$ & $2(15.4 \%)$ \\
\hline $\begin{array}{l}\text { Transmural or subendocar- } \\
\text { dial myocardial infarction } \\
\text { in the previous } 6 \text { months }\end{array}$ & $2(8.3 \%)$ & $1(7.7 \%)$ \\
\hline $\begin{array}{l}\text { Premature ventricular beats } \\
\text { (more than } 5 \text { per minute } \\
\text { documented at any time) }\end{array}$ & $15(62.5 \%)$ & $8(61.5 \%)$ \\
\hline $\begin{array}{l}\text { Rhythm other than sinus rhythn } \\
\text { or presence of premature atria } \\
\text { contractions on last pre- } \\
\text { operative electrocardiogram }\end{array}$ & $7(29.2 \%)$ & $5(38.5 \%)$ \\
\hline High-risk site of surgery & $14(58.3 \%)$ & $9(69.2 \%)$ \\
\hline Age over 70 years & $15(62.5 \%)$ & $7(53.8 \%)$ \\
\hline Aortic stenosis & $3(12.5 \%)$ & $3(23.1 \%)$ \\
\hline Emergency operatio & $2(8.3 \%)$ & $3(23.1 \%)$ \\
\hline Poor general medical condition & $10(41.7 \%)$ & $6(46.2 \%)$ \\
\hline
\end{tabular}

eral medical condition (71.4 versus 16.1 percent) and high-risk surgical sites (64.3 percent versus 32.4 percent) in the group with life-threatening complications or cardiac deaths, which may explain the poorer outcomes.

A more thorough evaluation of risks of the 24 class III and class IV patients who had no or minor cardiac complications was undertaken to determine whether there were any differences in risk factors to lead to better outcomes than were predicted. These figures are shown in Table 8. There are no significant differences in the occurrence of risk factors in the two groups; therefore, the differences in outcome must be attributed to either underlying risks not identified in patients with poorer outcome or to variations in patient management.

We found one other published report ${ }^{10}$ - a study of 6,043 surgical patients in a university medical center-that utilized Goldman and associates' cardiac risk factor index. Thirty of these patients died from cardiovascular causes. Of these, 7 patients could not be correctly classified for lack of sufficient information; 1 was identified as class I, 1 as class II, 12 as class III, 8 as class IV risks, and 1 patient (Goldman class 2) complained of severe chest pain immediately after cataract extraction and expired after cardiac arrest. Therefore, in this study, the high risk status of 20 of 23 patients who died of cardiovascular complications were correctly identified.

\section{Conclusion}

Concurrent cardiac disease adds a significant risk of morbidity and mortality for the patient who is undergoing noncardiac surgery. It is beneficial to identify these patients in the preoperative period to prevent or minimize cardiac complications. We found Goldman and associates' multifactorial index for cardiac risk in noncardiac surgery to be a valid system for identifying high-risk patients in our community osteopathic hospital. Therefore, we recommend the continued use of this risk factor index in the preoperative assessment of the surgical patient.

1. Tarhan, S., et al.: Myocardial infarction after general anesthesia. JAMA 220:1451-4, 12 Jun 72

2. Plumlee, J.E., and Boettner, R.P.: Myocardial infarction during and following anesthesia and operation. South Med J 65:886-9, Jul 65

3. Steen, P.A., Tinker, J.H., and Tarhan, S.: Myocardial reinfarction after anesthesia and surgery. JAMA 239:2566-70, 16 Jun 78

4. Goldman, L., et al.: Multifactorial index of cardiac risk in noncardiac surgical procedures. N Engl J Med 297:845-50, 20 Oct 77

5. Knapp, R.B., Topkins, M.J., and Artusio, J.F., Jr.: The cerebrovascular accident and coronary occlusion in anesthesia. JAMA 182:332-4, 27 Oct 62

6. Skinner, J.F., and Pearce, M.L.: Surgical risk in the cardiac patient. J Chron Dis 17:57-72, Jan 64

7. Goldman, L., et al:: Cardiac risk factors and complications in noncardiac surgery. Medicine 57:357-70, Jul 78

8. Goldman, L.: Guidelines for evaluating and preparing the cardiac patient for general surgery. J Cardiovasc Med 5:637-44, Jul 80

9. Goldman, L.: Cardiac risks and complications of noncardiac surgery. Ann Intern Med 98:504-13, Apr 83

10. Weathers, L.W., and Paine, C.: The risk of surgery in cardiac patients. Intern Med 2:57-64, Jan 81

Accepted for publication in April 1986. Updating, as necessary, has been done by the authors.

Dr. Nichols and Dr. Daniels were corecipients of a 1984 Mead Johnson National Osteopathic Foundation Fellowship Grant. This paper won first place in the resident paper contest of the American College of Osteopathic Internists in 1985.

At the time this paper was written, Dr. Nichols was chief medical resident at Oklahoma Osteopathic Hospital, Tulsa, where Wilbert W. Stoever, D.O., FACOI, is residency trainer. Dr. Nichols is now in the private practice of internal medicine in Mesa, Arizona. Dr. Daniels is a surgical resident at $\mathrm{OOH}$, where Michael H. Whitworth, D.O., is the residency trainer in surgery.

Dr. Nichols, 455 North Mesa Drive, Suite 16, Mesa, Arizona 85201 . 


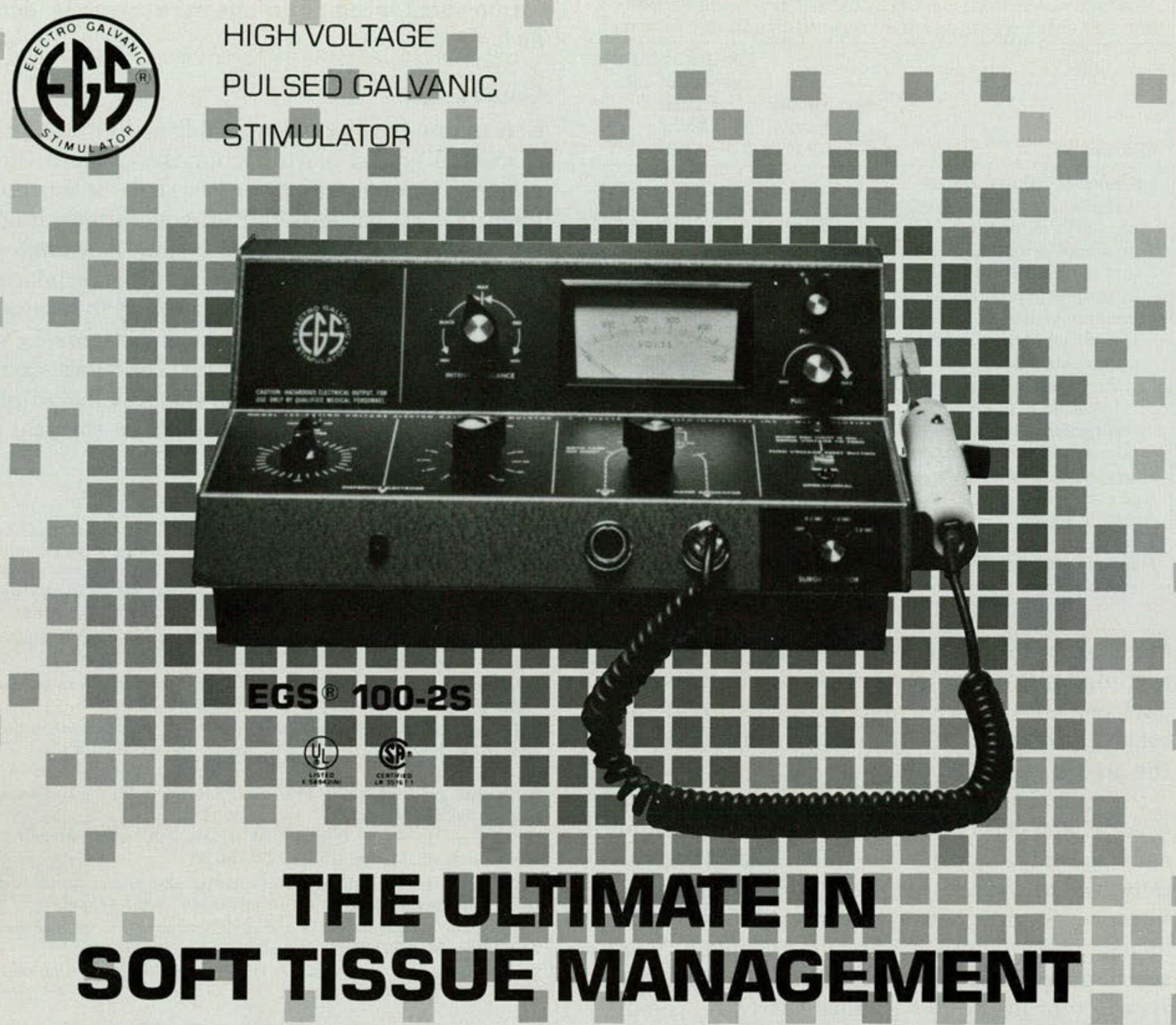

- Relieve spasticity and spasms (i.e. TMJ dysfunction)

- Increase local blood flow

- Delay atrophy from disuse in partially denervated muscle

- Re-educate muscle as in regaining joint control

- Stimulate calf post-operatively to prevent phlebothrombosis

- Relieve pain (EGS 300 only) when applied as a TENS

- Reduction of edema

- Totally safe

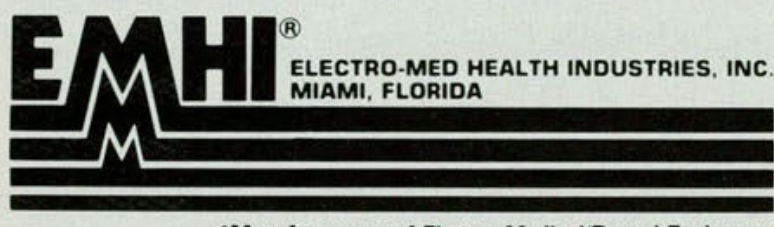

Manufacturers of Electro-Medical/Dental Equipment

6240 N.E. 4th Court $\cdot$ Miami, Florida 33138-6106 Phone: (305) 756-6013, Telex: 152303 EMHI UT

CAUTION: FEDERAL LAW RESTRICTS THIS DEVICE TO SALE BY OR ON THE ORDER OF A LICENSED PRACTITIONER.

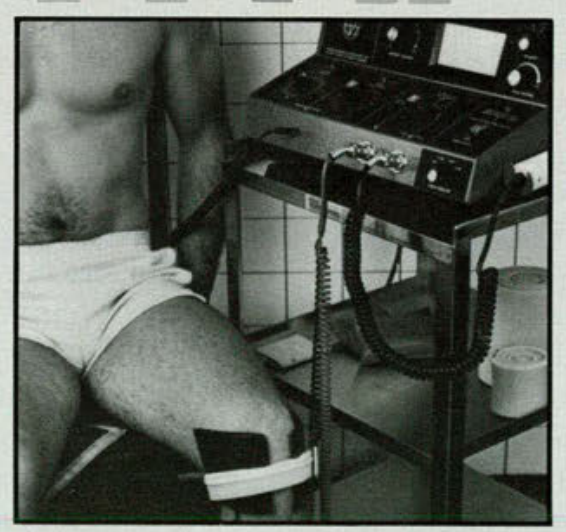

For more information clip and mail to:

ELECTRO-MED HEALTH INDUSTRIES, INC. 6240 N.E. 4th Court - Miami, Florida 33138

Name

Bus. Phone

Address

City

State Zip GYN37 